\title{
EL POEMA EXTENSO COMO INSTITUCIÓN CULTURAL FORMA POÉTICA E IDENTIDAD AMERICANA EN BELLO, HEREDIA Y ECHEVERRÍA
}

\section{LA SUPERACIÓN DE LA ÉPICA EN EL PROGRAMA ROMÁNTICO}

Uno de los muchos retos que el romanticismo planteó a los poetas occidentales consistió, probablemente, en liberar a la "gran poesía” del molde del poema épico en que estaba encorsetada desde la Antigüedad, y en llevar el principio de la Gattungsmischung ("fusión genérica") a la esencia misma del género que a partir de ese momento casi se identificará con la literatura: la poesía lírica. En la medida en que se pretende escribir poemas extensos que disuelven (en diferentes grados) el componente épico tradicionalmente asociado con aquéllos, se intenta trascender los exiguos márgenes por lo común característicos de la lírica, para sostener una enunciación subjetivo-sentimental a lo largo de una extensión textual considerable. Tal es una de las manifestaciones menos atendidas quizá de la revolución poética romántica, aun a pesar del anatema que Poe lanzaría contra el "poema extenso", por juzgarlo una contradicción en los términos $^{1}$, contradicción que, no obstante, si aceptamos que la ironía y la paradoja son poderosas herramientas románticas, volvería a enraizar el género en el marco de esa estética.

Friedrich Schlegel (autor a quien Echeverría citará en la "Advertencia" a uno de los poemas que constituyen el objeto

\footnotetext{
1 "The poetic principle", conferencia leída por PoE en varias ocasiones y publicada al parecer póstumamente (Home Journal, 31 August, 1850, p. 1, según referencia en www.eapoe.org/works/essays/poetprnb.htm). Puede verse la traducción cortazariana (Ensayos y críticas, de E. A. Poe, Alianza, Madrid, 1987, p. 81). BAUdELAIRE hablaría de "herejía de la extensión" ("Nuevas notas sobre Edgar Poe”, cit. por el texto incluido en Poesía completa de E. A. Poe, ed. bilingüe, Ed. 29, Barcelona, 1989, p. 67).
}

NRFH, LVI (2008), núm. 1, 87-122 
de este trabajo, La cautiva) apuntaba ya en 1797: "Ironía es la forma de la paradoja. Paradójico es todo aquello que es a la vez bueno y grande"2. Puede decirse que la mayoría de los poetas románticos buscará conjugar (irónica, paradójicamente ${ }^{3}$ ) esos dos principios, lo "grande" y lo "excelente". El deseo de amplitud, elevación, organización de un conjunto es también señalado por Schlegel como aspiración de la poesía romántica ${ }^{4}$.

Que semejantes ideas habían calado entre los poetas americanos del primer tercio del siglo XIX lo demuestran unas declaraciones del ya mencionado Echeverría (en carta a Juan María Gutiérrez), que no será precipitado consignar en este momento:

En poesía para mí, las composiciones cortas siempre han sido de muy poca importancia, cualquiera que sea su mérito. Para que la poesía pueda llenar su misión profética, para que pueda obrar sobre las masas y ser un poderoso elemento social, y no como hasta aquí, entre nosotros y nuestros padres, un pasatiempo fútil y, cuando más, agradable, es necesario que la poesía sea bella, grande, sublime y se manifieste bajo formas colosales ${ }^{5}$.

El problema de la "amplitud" y las "formas colosales" a que se refiere aquí Echeverría apunta, de modo directo, a la cuestión de las relaciones (no menos paradójicas) entre la unidad del texto y la diversidad de las partes ${ }^{6}$. En otras palabras, se insinúa ahí el problema del fragmentarismo, modo de composición típicamente moderno, que deja huella explícita en algunos de los textos que consideraremos ${ }^{7}$.

2 Frag. 48, p. 74, cito por "Fragmentos del Lyceum" (1797), en Fragmentos para una teoría romántica del arte, ed., sel. y trad. J. Arnaldo, Tecnos, Madrid, 1987, pp. 72-77.

3 Cabría decir "anti-barrocamente", en la medida que Schlegel propone el ideal contrario al gracianesco que conjuga bondad con brevedad.

${ }^{4}$ Frag. 116 del Athenäum, 1798, en Fragmentos para una teoría..., p. 137.

${ }^{5}$ Carta cit. por Juan María Gutiérrez, escrita poco antes de la aparición de Los consuelos (1834). Véase Echeverría, Obras completas, Buenos Aires, 1874, t. 5, p. lx, apud Emilio Carilla, El romanticismo en la América Hispánica, t. 2, Gredos, Madrid, 1967, p. 12.

6 Véase, de nuevo, a Schlegel: "También en la poesía bien puede ser mitad todo conjunto y toda mitad, ciertamente, conjunto" (frag. 14, en Fragmentos para una teoría..., p. 72).

${ }^{7}$ Baste una sola cita en relación con un poeta español, Espronceda: “...el fragmentarismo y la digresión son trazos rituales en la composición del poema romántico que se justifican por su naturaleza de expresión desarticulada de la angustia que viven los románticos, quienes traducen a un ritmo sentimental 
Pero antes de continuar hacia ese horizonte, conviene señalar que en el "programa romántico" fundacional elaborado por Schlegel aparece alguna otra nota interesante para empezar a contextualizar la importancia del poema extenso en este período. Por un lado, hay que mencionar el peso considerable que tendrá lo que podría llamarse "estructura visionaria" (anticipada, no obstante, en poemas extensos barrocos como el Sueño de sor Juana ${ }^{8}$ ), también definido por Schlegel, en relación con las dimensiones de la obra:

Una obra lo es cuando está fuertemente limitada por todas partes y es ilimitada e inagotable dentro de los límites, cuando es completamente fiel a sí misma, igual en todas sus partes, y además sublime por encima de sí misma. Lo último y lo más alto es, como en la educación de un joven inglés, le grand tour. Ha de viajar por las dos o tres regiones del mundo de la humanidad, no para rebajar las aristas de su individualidad, sino para ensanchar su mirada y para que su espíritu adquiera más libertad y multiplicidad interna y, en consecuencia, mayor independencia y autosuficiencia ${ }^{9}$.

El dinamismo espacial y el impulso de máxima expansión subjetiva típicamente romántico encontrarán en el "poema extenso" el cauce más adecuado. Pero es importante señalar, por otra parte, que en el programa de Schlegel aparece también apuntada una cuestión de implicaciones histórico-literarias trascendentales: la posibilidad de sustituir la epopeya como género privilegiado en el canon literario, logrando la fusión entre objetividad y subjetividad. En el famoso fragmento 116 del Athenäum (1798), en el que Schlegel definía la poesía romántica como "una poesía universal progresiva”, y afirmaba que el "arbitrio del poeta” era su máxima ley, sostenía:

Como la epopeya, sólo ella [esto es, la poesía "universal progresiva"] puede devenir espejo de la totalidad del mundo circundante, imagen de la época. Y es, eso sí, superior su capacidad para volar con las alas de la reflexión poética entre lo representado y lo que representa,

su vivencia lírica” (LEONARdo RoMero Tobar, "Introducción” a Obras poéticas, de J. de Espronceda, Planeta, Barcelona, 1986, p. liii).

${ }^{8}$ Como no se ha cansado de recordar Octavio Paz en sus estudios sobre el "poema extenso" o sobre la "Décima musa" (cf. "Contar y cantar [sobre el poema extenso]", en La otra voz. Poesía y fin de siglo, Seix-Barral, Barcelona, 1990, pp. 11-30 y Sor Juana Inés de la Cruz o Las trampas de la fe, F.C.E., Bogotá, 1997).

${ }^{9}$ Frag. 297 del Athenäum, en Fragmentos para una teoría..., p. 141. 
en el centro, libre de todo interés real e ideal, y puede potenciar una y otra vez tal reflexión, y reproducirla infinitamente en un continuo de espejos ( $i d$. ; las cursivas son mías).

Sin duda, textos como Al Popocatepetl, En el teocalli de Cholula (ambos de 1820 y con 218 y 151 vv. respectivamente), Niágara $(1824,231$ v.) y Placeres de la melancolía (1825, 308 vv.), de José María Heredia; la Alocución a la poesía (1823, 834 vv.) y A la agricultura de la zona tórrida (1826, 373 vv.), de Andrés Bello; y, finalmente, La cautiva (1837, 1945 vv.), de Esteban Echeverría, buscaron realizar el proyecto de Schlegel de reflejar la "imagen de la época", "volando con las alas de la reflexión poética". Estos poemas consiguieron así que, ya para la década de los años cuarenta, en el ámbito hispánico, la epopeya fuera considerada un género anacrónico y desenfocado ${ }^{10}$.

Como ya señalara Van Tieghem, el poema extenso se convirtió en la forma que ofrecía más posibilidades de renovación a los románticos porque, paradójicamente, era el ámbito más reglamentado por la poética clásica ${ }^{11}$. Se convirtió, preferentemente, en un género de carácter contaminado, "épico-filosófico”, en el que se veía el mejor cauce para "volver sensibles las ideas abstractas"12 y que daría lugar a poemas protagonizados por héroes simbólicos que se mueven libremente por espacios reales, imaginarios o simplemente indeterminados (p. 364). Algunas de estas características aparecerán en los poemas que analizaremos, pero es preciso asumir que la superación del canon épico es, necesariamente, un proceso gradual.

La mayoría de estos poemas extensos románticos -como también apunta Van Tieghem (p. 373)- son, sin embargo, más cor-

10 Cf. L. Romero Tobar, Panorama crítico del romanticismo español, Castalia, Madrid, 1994: “...los intentos por continuar la escritura épica no fueron sino anacronismos y desenfoques, tal como ha calificado Díaz Larios el proyecto épico sobre Hernán Cortés que ocupó a García Gutiérrez durante su estancia americana de 1845 a 1846” (p. 197). Las fechas indicadas para los poemas son las de las versiones conocidas más antiguas; la extensión, sin embargo, es la de las ediciones manejadas en cada caso. A veces, diferentes ediciones han modificado la extensión: para el caso de Placeres..., En el teocalli... o Niágara de Heredia, por ejemplo, cf. Tilmann Altenberg, Melancolía en la poesía de José Maria Heredia, Vervuert-Iberoamericana, Frankfurt/M.-Madrid, 2001, pp. 41, 154 y 156 , respectivamente.

11 Paul van Tieghem, Le romantisme dans la littérature européenne, Albin Michel, Paris, 1969, p. 348.

12 P. van Tieghem, op. cit., p. 363. 
tos que las epopeyas tradicionales, aunque las recuerdan por su tono y su versificación más o menos uniforme. Para el caso hispánico, sin embargo, el molde barroco de la silva-que practicaron Heredia, Bello y Echeverría- introducirá un nuevo factor de disolución. Por otro lado, no será siempre absoluta la ausencia, en estos poemas, de lo que Van Tieghem considera "ingredientes rituales de ese género anticuado", como los sueños, el relato del héroe o las apariciones.

Es preciso por ello insistir en el aspecto "gradual" de este proceso de superación del canon épico. De hecho, sueños y visiones serán cauce privilegiado para la proyección de la imaginación romántica liberada, y, si acaso, la diferencia con relación a la presencia de estos recursos estructurales en los poemas épicos clásicos estriba en que si en aquéllos su función era de carácter alegórico y artificioso, el poema extenso romántico los utilizará como mecanismos de ese proceso de "máxima expansión subjetiva" que ya hemos tenido ocasión de señalar. Es la diferencia que hay entre los sueños de Ercilla en La Araucana (mero pretexto para ampliar la materia hacia territorios que la verosimilitud no permitiría alcanzar de otra manera) y los sueños y las visiones de Heredia en los poemas que consideraré: "emanaciones directas" -podría decirse- de la contemplación de la arquitectura o la naturaleza americanas y que, aun en el caso en que su inserción más se asemeja a la estructura épica (En el teocalli de Cholula, quizás), difiere de ella en que el poema termina sin que el poeta haya declarado haber salido de su sueño.

La presencia de un héroe simbólico y la importancia del decorado, los sentimientos y las aventuras como espacios de la imaginación romántica (cf. id.) suscitan la consideración de otro de los géneros hacia los que deriva el poema épico en el período que nos interesa: el "poema narrativo". Si los textos de Heredia y Bello que tomaremos en consideración se adscriben más bien al género épico-filosófico o épico-descriptivo, La cautiva de Echeverría -mucho más extenso- cumple con mayor propiedad los rasgos de esta otra manifestación de las "formas colosales" que el propio autor reclamaba en la carta a Gutiérrez antes citada. La incorporación de materiales de las tradiciones nacionales y el olvido de las reglas de "decoro", que permiten mezclar esos materiales con otros de muy diversa procedencia (clásica o bíblica, por lo común) constituyen, según Romero Tobar ${ }^{13}$, una

13 “Introducción” a Obras poéticas de Espronceda, p. xlii. 
de las primeras características de estos textos que quieren seguir siendo considerados poéticos. A ello se añade la posibilidad de integrar en un cauce narrativo el componente descriptivo (herencia del siglo XVIII), así como "la mímesis del diálogo teatral y la expresión desnuda de la voz lírica"14.

Desde la década de los años veinte del siglo xix, el poema narrativo se desarrolló en todas las literaturas europeas. La cautiva es uno de los primeros textos en español adscritos a ese género (si acaso precedido por El moro expósito del Duque de Rivas en 1834 o aun por Elvira o la novia del Plata, del propio Echeverría, publicado en 1832) y su desarrollo alcanzará hasta los textos clave del último tercio del siglo xix: Martín Fierro $(1872$ y 1879) y Tabaré (1888), considerados fundacionales en sus respectivas literaturas. Las dimensiones de La cautiva, no obstante (1945 vv., frente a los más de 7000 del Martín Fierro -en sus dos partes- o los casi 5000 del Tabarê), y la relativamente menor importancia del argumento frente a la descripción de la naturaleza y de los sentimientos de los protagonistas, acercan el poema de Echeverría al género fronterizo del "poema extenso lírico" y permiten considerarlo como un texto de transición entre los poemas de Bello y Heredia de los años veinte y los grandes poemas narrativos de finales de siglo, más cercanos a una posible revitalización del género épico que acaso ha olvidado ya el programa romántico de fusión genérica o ha resuelto, de un modo u otro, sus tensiones, aún presentes en los textos que queremos considerar.

Ya Emilio Carilla vio en estos poemas americanos "de cierta extensión” la preferencia por lo descriptivo y subrayó, entonces, de modo indirecto, su importancia como género privilegiado para la representación de la "rica y cambiante naturaleza americana" 15 . Al matizar que en ellos se inaugura "un paisaje literario nítidamente local”, Carilla estaba señalando, a mi juicio, la diferencia con respecto a los poemas descriptivos manieristas o barrocos, igualmente extensos (como Grandeza mexicana, de Bernardo de Balbuena, 1604), mucho más atados a las convenciones de un paisaje literario, aunque ya pudiera entreverse en ellos algún atisbo de la realidad propiamente americana.

La introducción del rasgo "local", por otra parte, abre la puerta a la inscripción de la historia en el poema extenso más o menos descriptivo, en la medida en que lo específico (americano o mexi-

14 L. Romero Tobar, Panorama crítico..., pp. 197-198.

15 Op. cit., p. 12. 
cano o venezolano o argentino) de esos poemas era el resultado de un proceso de disolución de una quizá paradójica identidad colonial, proceso que iba paralelo a la disolución del canon épico. Esa combinación de naturaleza e historia será, entonces, según Carilla, característica del poema extenso romántico hispanoamericano:

En Hispanoamérica se escribieron numerosos poemas extensos, construidos sobre una anécdota casi siempre de tema histórico. En esos poemas solían insertarse descripciones de la naturaleza, retratos, comentarios líricos. El resultado... era un poema de cierta extensión, al cual llamamos "poema narrativo lírico”... (ibid., p. 16).

Aunque Carilla establece un corpus de los que él llama "poemas narrativo-líricos" inaugurado por La cautiva y culminado por el Martín Fierro, a mí me interesa más adoptar otra perspectiva, que acabo de apuntar, y prefiero considerar La cautiva como texto en el que culmina un proceso de disolución del canon épico por contaminación de rasgos líricos, iniciado hacia los años veinte por poemas como los de Heredia y Bello. Extremada esa tensión en el texto de Echeverría, el discurso poético emprende un camino de retorno hacia la narratividad épica que, pasando por las leyendas en verso, desembocará en la escritura de poemas "fundadores" de las tradiciones nacionales, pero que estaban ya alejados del impulso "experimental" que acaso había caracterizado a los textos que consideraré.

\section{EL POEMA EXTENSO Y LA CRISIS DE LA CONCIENCIA COLONIAL}

En este punto se alcanza, entonces, la formulación de mi hipótesis de trabajo: se pretende aquí integrar el análisis de una forma con el análisis de una perspectiva ideológica, para elucidar eventuales vínculos entre ambas. La forma es la del "poema extenso"; la "perspectiva ideológica" es la de la construcción de la identidad americana en el siglo xix. Desde la consideración "crítica" del poema extenso romántico, que asume la condición de género liminar o umbral estético, resulta especialmente interesante preguntarse por sus relaciones (en esa temprana época que abarca de 1820 a 1840) con la crisis de la conciencia "colonial".

En lo que sigue, trataré de explorar cómo la poesía hispanoamericana intentó superar el molde del poema épico, tradicionalmente asociado a los discursos fundadores, para hollar los 
márgenes de la subjetividad lírica, sin renunciar al rasgo de la extensión. La atención a las dimensiones del texto, en este marco, es fundamental, puesto que el "poema largo", al tiempo que permitía desarrollos demorados -tanto de cuestiones juzgadas de interés colectivo como de visiones individuales- aparecía como una proyección analógica de la vastedad de la materia del poema y -lo que no es menos importante- podría garantizar, en virtud de su propia envergadura textual, su "visibilidad", su capacidad representativa y, así, su perduración como institución cultural.

Conviene declarar desde el principio que el cauce que ha de seguir mi interpretación sigue el modelo de un ensayo muy iluminador de Smaro Kamboureli, referido a la literatura canadiense $^{16}$, y que pone en circulación ideas tal vez provechosas para una nueva lectura de la poesía hispanoamericana de este período. Enfrentándose a la importante presencia del "poema extenso" en la tradición poética anglocanadiense, Kamboureli realiza una síntesis de los elementos que podrían justificar la "visibilidad" de ese género en su ámbito geográfico, desde el siglo xix. Su planteamiento presenta un nivel de abstracción teórica que invita a proyectar algunas de sus hipótesis sobre otras tradiciones poéticas, tal como se hallaban en el mismo siglo, aun cuando su estatuto político fuera diferente, pues no se puede ignorar que mientras Canadá era todavía una colonia, los territorios hispanoamericanos estaban disolviendo sus vínculos con la metrópoli y adquiriendo su independencia.

Los poemas que he elegido para mi análisis resultan especialmente interesantes, desde este punto de vista, no obstante, porque, por un lado, los más tempranos (los de Heredia) suelen adscribirse (el propio autor lo hace) a una tradición, la cubana, todavía "dependiente" o colonial en ese momento, aunque fueron escritos en México y se refieren al contexto histórico-geográfico mexicano o bien al Niágara, referente norteamericano que constituyó una piedra de toque para la poesía hispanoamericana romántica y post-romántica (recuérdese el poema de Rafael Pombo, de 1860, o el de Pérez Bonalde, de 1892, que suscitará

\footnotetext{
16 Smaro Kamboureli, On the edge of genre. The contemporary Canadian long poem, University of Toronto Press, Toronto, 1991. En este ensayo se apoya uno de los pocos estudios más o menos generales que hay sobre el poema extenso hispanoamericano: MinetTe Riordan, Visionary imaginations: The crisis of modernity in three Chilean long poems, tesis doctoral, Stanford University, 1995, quien, sin embargo, no habla del siglo xix sino de Gabriela Mistral, Vicente Huidobro y Pablo Neruda.
} 
el prólogo-manifiesto modernista de Martí). Por otro lado, los demás textos que consideraré se escriben en un momento de inmediata consolidación de la independencia hispanoamericana (1824 es el año de las batallas de Junín y Ayacucho que oficialmente parecen poner fin al proceso) y pretenden contribuir a dicha consolidación (Bello); o bien se escriben en el período de constitución de la identidad nacional (argentina) en oposición a la tiranía (de Rosas), yugo no menos pesado al parecer que el colonial, sugiriendo un doble principio ideológico que articule esa construcción (la atención a la tierra y el amor). La confrontación de los presupuestos de una tradición "colonial" (la canadiense en el momento indicado) con unos textos pertenecientes a una tradición que podríamos llamar "post-colonial" temprana puede tal vez arrojar luz sobre el diferente significado de "colonial" según se aplique al ámbito político o literario.

1. Así las cosas, una investigación sobre el poema extenso hispanoamericano en el siglo XIX podría, siguiendo libremente el modelo citado, comenzar con una cuestión de base: la que plantea la posibilidad de establecer una relación entre una cultura concreta como "institución ideológica" y el surgimiento de un género particular ${ }^{17}$. Se trata de aclarar si la presencia de un género-forma determinado se corresponde mejor que otros con un determinado propósito, tradición o contexto.

A mi juicio, tanto para el poema extenso hispanoamericano romántico como para otros de otras tradiciones, esa relación no puede ser sino tenue y meramente analógica. El rasgo formal de la extensión textual puede relacionarse con el surgimiento de la institución ideológico-cultural independiente sólo por la duración de sus respectivos procesos de composición. En ese sentido, se puede decir que las literaturas independientes en Hispanoamérica van surgiendo a la vez que se van escribiendo esos poemas.

Es notable, por ejemplo, la "paulatina, laboriosa y dilatada gestación"18 de En el teocalli de Cholula de Heredia ${ }^{19}$, con una pri-

17 “...these critics' emphasis on the Canadian context suggests that Canadian culture seems to function as an ideological institution that is amenable to the production of the long poem as genre" (S. KAmBoureli, op. cit., p. 7).

18 Manuel Pedro González, “José María de Heredia”, José María de Heredia, primogénito del romanticismo hispano. Ensayo de rectificación histórica, El Colegio de México, México, 1955, pp. 91-102; recogido en Historia y crítica de la literatura hispanoamericana, ed. C. Goic, Crítica, Barcelona, 1991, t. 2, p. 130.

19 José María Heredia, En el teocalli de Cholula [1820], en Niágara y otros textos 
mera versión en 1820; una primera publicación en 1825 y una segunda publicación en 1832, pero con supresiones, modificaciones y añadidos ${ }^{20}$. Otro tanto podría decirse del proyecto de un poema titulado América de Bello ${ }^{21}$, que quedaría inconcluso, en una sugerente analogía -acaso- con el proceso de construcción de la identidad americana independiente ${ }^{22}$. También Echeverría, una vez publicada La cautiva (sobre cuya composición no abundan los datos, al parecer), ocuparía buena parte de la década de los años cuarenta en el exilio elaborando su más vasto proyecto poético que, al parecer, se iba a plasmar en dos extensos poemas de carácter más o menos autobiográfico-político ( $L a$ guitarra o primera página de un libro-1842-y la primera parte de El ángel caído-1846-) y aun otro no realizado ("Pandemonio")23.

2. La siguiente cuestión tiene un alcance histórico-literario más específico y atañe directamente a las posibilidades de construcción de una literatura independiente de los modelos metropolitanos. Se trata, ahora, de entender hasta qué punto esos modelos han sido o no adaptados al nuevo contexto 24 .

Para el caso del poema extenso, es evidente que los poetas hispanoamericanos trabajan a partir de moldes establecidos por la tradición clásica, como son fundamentalmente la oda y la silva. La oda, género extenso lírico en su origen pindárico y horaciano, había ido convirtiéndose desde el siglo Xviı en género fronterizo, que permitía contaminar lo lírico-subjetivo con lo cívico ${ }^{25}$

(poesía y prosa selectas), sel., pról. y cron. A. Augier, Ayacucho, Caracas, 1990, pp. 106-109.

${ }^{20}$ Los problemas textuales de la obra de Heredia están bien considerados en T. AltenberG, op. cit., pp. 286-288, n. 40.

${ }^{21}$ Para los detalles, es imprescindible el artículo de Guillermo Araya, "América en la poesía de Andrés Bello", Homenaje a Andrés Bello en el bicentenario de su nacimiento (1781-1981). Diálogos Hispánicos de Amsterdam, 1982, núm. 3, 49-95.

22 Como sugiere Miguel Gomes, "Las silvas americanas de Andrés Bello: Una relectura genológica”, HR, 66 (1998), p. 194.

23 Cf. LeOnor Fleming, "Introducción" a El matadero/La cautiva, de Esteban Echeverría, Cátedra, Madrid, 1990, pp. 52-53.

24 "The long poems of nineteenth-century Canada mark the beginning of a literature that is linear exactly because it transfers the British tradition without necessarily adapting it to the colonized country" (S. KAMBOURELI, op. cit., p. 10).

25 "En el siglo XVIII se había registrado una corriente en la teoría y la crítica occidental -que influyó naturalmente sobre los poetas- cuyo fin era aminorar la atención a la poesía lírica a favor de la oda. Esa actitud se enrai- 
y ése será el modelo que utilizarán los cantores de la independencia. No obstante, el cambio romántico propiciaría un cierto abandono del alcance público del poema y la mayor atención a la intimidad del poeta, que optaría por el canon elegíaco ${ }^{26}$, del que es singular muestra Placeres de la melancolía de Heredia, pero también algunos fragmentos de la Alocución de Bello y no pocos pasajes de La cautiva.

La silva, por otro lado, es quizá el cauce formal más usado en el intento de superar el canon épico y de escribir poemas extensos de tonalidad lírica. Ya en el barroco la silva extensa había supuesto una innovación específicamente hispánica, a partir de Góngora. En el caso de Heredia, su uso parece preferir la referencia implícita a modelos americanos: la presencia del "sueño" en En el teocalli de Cholula no deja de evocar el poema Primero Sueno de sor Juana, a veces con alusiones más o menos explícitas ${ }^{27}$. En otros lugares del poema de Heredia, sin embargo, el sueño tiene un carácter "menos asimilado", más "antiguo", más épico, en la medida en que sirve como pretexto para transportar al yo a un tiempo pasado, "la profunda noche de los tiempos" (v. 103). En cualquier caso, sus modelos son de tradición hispanoamericana (sor Juana, Ercilla), aunque también Heredia se inspira al parecer en algún texto norteamericano ${ }^{28}$.

zaba, consecuentemente, en la concepción filosófica de Platón, que había desterrado a la lírica de su ideal República (Libro X) porque no la consideraba un medio idóneo para el conocimiento y la revelación de la verdad a sus destinatarios siempre latentes. Contrariamente a esos fines pragmáticos, la poesía sólo podía imitar... el modelo de Píndaro ocupó el relieve entre las normas neoclásicas" (ÓSCAR RIVERA-RODAs, La poesía hispanoamericana del siglo XIX, Alhambra, Madrid, 1988, p. 52).

26 “...como Heredia, la gran mayoría de los líricos hispanoamericanos elegirá también la elegía y preferirá dejar la oda. El «yo lírico» se encontraba más cómodo y mejor habilitado para desbordar sus sentimientos a través de la elegía. El romántico no sólo prescindió de la naturaleza que había sustentado el arte clasicista, sino también del público" (O. Rivera-RodAs, op. cit., p. 77).

${ }^{27}$ Entre los vv. 52-99 se representa un anochecer y la contemplación del cielo estrellado, que envía una luz que hace crecer la sombra del Popocatepetl: "En sombra universal veló la tierra" (p. 74), lo que no deja de evocar el principio del Primero Sueño. El número que sigue a las citas es siempre el del verso, en las ediciones consignadas.

28 Según M. P. GonzÁlez, En el teocalli de Cholula revela una posible influencia de $A$ walk at sunset de William Cutler Bryant, poeta norteamericano con quien Heredia pudo coincidir en Boston (1823) y luego en Nueva York (1824-1825). Como señala González, el poema de Bryant se publicó en 1821 y Heredia pudo conocerlo y tal vez modificar el planteamiento del suyo. Ambos 
El poema Niágara ${ }^{29}$ también permite traslucir la presencia de modelos anteriores americanos: la descripción de una procelosa corriente de agua no deja de evocar el celebérrimo romance gongorino al "arroyo de Chillo" de Hernando Domínguez Camargo en el siglo XviI y, de nuevo, la aparición de una "luminosa pirámide" (v. 51) evoca la contraria "piramidal... sombra" de sor Juana. En Placeres de la melancolía, sin embargo, el modelo elegíaco se acoge al topos clásico del ubi sunt, inevitable en ese tipo de poemas, al menos -para la tradición hispánica-desde las Coplas de Manrique. El tono, sin embargo, es reivindicativo: “ $¿ D o$ fue la raza candorosa y pura / que las Antillas habitó?..." (vv. 178-179) o aparece cargado de implicaciones políticas: es el exilio el que hace preguntarse al poeta por algunos elementos de su patria: “¿Dó están las brisas de la fresca noche....?” (v. 277); “¿Dónde las nubecillas...?” (v. 281). Heredia, entonces, no rehúye los moldes que estaban a su disposición, pero la utilización explícita que hace de las formas o de los tópicos le llega por mediación de modelos americanos o bien aparece modificada por la circunstancia histórica.

El caso de Bello es más complejo, en la medida en que, sobre todo en la Alocución, reclama una traslación de la Poesía del Viejo al Nuevo Mundo, lo que implica, necesariamente, una valoración positiva de los modelos ${ }^{30}$. Lauterbach ha relacionado ese reclamo con el tópico clásico de la translatio de capacidades (imperii, religionis, studiorum), que, sin embargo, no encontró tanto reflejo en la literatura hispanoamericana como en la norteamericana. Bello, al parecer, es un caso excepcional y, sin duda, debe ponerse en relación de precedencia con la confianza "mundonovista" (a fines del siglo xIX y principios del xx) en la regeneración de la cultura occidental en América. La excepcionalidad del motivo

poemas se parecen en el tono crespuscular, la actitud contemplativa y serena, la suave melancolía y el sentimiento elegíaco atenuado, así como otros detalles: "Me inclino a creer que Heredia reelaboró su poema entre 1823 y 1825 después de leer «A walk at sunset»" (art. cit., p. 132).

${ }^{29}$ J. M. Heredia, Niágara [1824], en Niágara y otros textos..., ed. cit., pp. 140-143.

30 Según Frank Lauterbach sus descripciones pueden aplicarse a cualquier lugar y son resultado "de un paisaje idealizado de su mente" ("Escribir al Oeste, mirar al Este: Andrés Bello y el curso de la poesía”, en Do the Americas have a common literary history?, eds. B. Buchenau, A. Paatz \& A. P. Frank, P. Lang, Frankfurt/M., 2002, p. 184), a partir de intertextos mitológicos (Virgilio, pero también Pope). 
en Bello puede deberse, según Lauterbach, a su contacto con la cultura anglosajona entre 1810 y 1829 (durante su exilio en Londres) ${ }^{31}$, con lo que encontramos también un elemento de renovación de la cultura metropolitana en su contacto con otras tradiciones. Además, el carácter "performativo" de la Alocución (como speech act) parece introducir una modulación intencional: el traslado (de la Poesía, en este caso) no es resultado de ningún designio "providencial" -implícitamente colonial-sino fruto de una acción humana concreta (ibid., p. 182).

En cuanto a la utilización de modelos formales más o menos adaptados, el caso de Bello es especialmente interesante por su reinvención de la silva, inscribiendo desde el principio alusiones al patrón gongorino: como señala Gomes, las palabras "soledad" y "selva" aparecen ya en los primeros versos de la Alocución $n^{32}$. La lectura que establece la homología entre silva y selva tiene tradición clásica, pero en Bello parece apoyarse no sólo en el significado metafórico (la "silva" como "selva" abigarrada de motivos y modos poéticos $\left.{ }^{33}\right)$, sino además como forma más adecuada para transcribir la materia americana, entendida como "mundo

31 “...la realización concreta del motivo en el poema de Bello, al igual que en un ensayo escrito en 1844 [ «Respuesta al discurso de Lastarria: Investigaciones sobre la influencia de la conquista y del sistema colonial de los españoles en Chile»], revela la persistencia de una ideología anglogermánica, y no el trabajo de una tradición desarrollada de manera muy diferente en los países románicos..." (F. LAUTERBACH, art. cit., p. 176).

32 Andrés Bello, "Alocución a la poesía-Fragmento de un poema titulado América (Silvas americanas)" [1823], Biblioteca Americana, London, en Obra literaria, sel. y pról. P. Grases, cron. O. Sambrano Urdaneta, Ayacucho, Caracas, 1985 [1979], pp. 20-40.

${ }^{33}$ La heterogeneidad era característica del género "silva” y podría justificar la supuesta "incoherencia" de la obra de Bello: "La Alocución es una empresa en cierto modo compiladora, como la gongorina... Si hay selva de versos y de asuntos, también la habrá de géneros o modalidades genéricas, no sólo literarias" (M. Gomes, art. cit., p. 188). Esa heterogeneidad, esa dispersión es por otra parte la que permite utilizar la silva como mecanismo de disolución del canon épico: el propio Bello, en un texto en el que alaba el Canto a Bolívar de Olmedo (1826), silva también, afirma: "es característico de la poesía lírica no caminar directamente a su objeto. Todo en ella debe parecer efecto de una inspiración instantánea: el poeta obedece a los impulsos del numen que lo agita sin la menor apariencia de designio, y frecuentemente lo vemos abandonar una senda y tomar otra, llamado de objetos que arrastran irremisiblemente su atención...; reina en toda la obra una variedad que la naturaleza del asunto apenas permitió esperar" (Obras completas, t. 9, pp. 228229 apud M. Gomes, art. cit., p. 191). 
silvestre". En esa "sincronización" entre forma y fondo ve Gomes el origen de un "género nuevo" específicamente americano y hasta "independentista", que tendría una proyección excepcional posteriormente ${ }^{34}$ y en la que también se integraría la silva $A$ la agricultura ... ${ }^{35}$. Sin embargo, la analogía forma-materia que va al parecer dando lugar a un género nuevo, debería ser matizada. A juicio de Bello, en la Alocución, no sólo América es "mundo silvestre", sino que la misma poesía es "silvestre ninfa" (v. 24), que ama lo primitivo y la "nativa rustiquez". Por otra parte, en A la agricultura... (que sigue siendo "silva" poética; de hecho es la única composición que se denomina así explícitamente en el corpus de Bello ${ }^{36}$ ), la "selva" americana se transforma en campo cultivado. Hay, entonces, implícito un posible programa estético que permite la consolidación de logros formales más o menos experimentales, mientras que postula un mensaje "moderado", de carácter "clásico": "... al vulgo bravío / de las tupidas plantas montaraces, / sucede ya el fructífero plantío / en muestra ufana de ordenadas haces" (vv. 252-255). La "nativa rustiquez" de la Alocución, que podía ser estímulo para el traslado de la poesía del Viejo al Nuevo Mundo, de nada sirve si no se convierte allí en "fructífero plantío". El programa de Bello es de "re-generación" y, por tanto, de respeto a los modelos metropolitanos-clásicos.

De los autores que analizo en este trabajo, Echeverría es el que con más conciencia reclama la condición de "originalidad" respecto de modelos anteriores (de índole colonial). La crítica

34 "América, el mundo silvestre, se entiende con la Poesía en silvas... Si pensamos en todos los poetas que repetirán la iniciativa, podría afirmarse que así nacía uno de los primeros géneros hispanoamericanos modernos. ¿En qué consistía?: en la sincronización de una forma y un fondo... el modelo genológico que lo produjo fue básicamente mimético: el escritor «copiaba» el universo al que se refería" (M. Gomes, art. cit., p. 187).

35 "Bello... vislumbró la existencia de un género literario nuevo, y no sólo eso: nuevo como el Nuevo Mundo al que había invitado a la poesía. Si la Alocución constituía un repertorio de registros morfotemáticos posibles, géneros aptos para ser desarrollados en el continente, La agricultura se concentrará en uno de ellos, el geórgico-descriptivo, así como el texto de Olmedo [Canto a Bolívar] había reelaborado espléndidamente el pindárico-heroico" (M. Gomes, art. cit., p. 192). Otros títulos que cita Gomes (p. 193) son: A Cumaná de Luis Alejandro Blanco; Batalla de Ayacucho, de Félix Soublette; A Bolívar, de Vicente Coronado; Libertady La Patria, de Marco Antonio Saluzzo; además de muchos poemas de Heredia posteriores a Niágara (entre los que incluye también Placeres de la melancolía) o el Canto al general Flores de Olmedo.

36 A. BELlo, "La agricultura de la zona tórrida. (Silvas americanas)" [1826], Repertorio Americano, London; en Obra literaria, ed. cit., pp. 40-49. 
ha señalado, no obstante, los límites y debilidades de su renovación formal en La cautiva ${ }^{37}$, en la medida en que el experimento métrico que a menudo sustenta el poema no excluye la caída en el ripio o a veces cierta inconsistencia estructural o ideológica. En el propósito del autor (tal como se expresa en la "Advertencia” inicial) está evitar "reducir su obra a una mera descripción" (p. 117), el otro cauce tradicional del poema extenso (al lado de la modulación épica). Para ello decide combinarlo con el análisis de una pasión e introduce dos "seres ideales", "dos almas unidas por el doble vínculo del amor y el infortunio" (id.). Además, Echeverría desdeña explícitamente los modelos y la preceptiva:

La forma, es decir, la elección del metro, la exposición y estructura de La cautiva, son exclusivamente del autor, quien, no reconociendo forma alguna normal en cuyo molde deban necesariamente vaciarse las concepciones artísticas, ha debido escoger la que mejor cuadrase a la realización de su pensamiento (p. 119).

El impulso de originalidad le lleva incluso a apartarse del molde de la silva, para acercarse al más romántico cauce del poema polimétrico ${ }^{38}$. Conscientemente, pretende ennoblecer el uso del octosílabo "aplicándolo a la expresión de ideas elevadas y profundos afectos" (p. 120). Todo el interés de la renovación formal-métrica, apoyada en la variedad rítmica, que Echeverría pretende se justifica por una razón trascendente que establece una interesante analogía entre el personaje-motivo del poema y el lector: el ritmo, para Echeverría, "es la música por medio de la cual la poesía cautiva los sentidos y obra con más eficacia en el alma" (id.; las cursivas son mías). El alma y los sentidos del lector, cautivos en el poema, serán un equivalente de María, cautiva en el desierto. Semejante analogía entre poema y desierto se verá reforzada, justamente, por las dimensiones: ambos son vastos, como se verá más adelante. Pero ahora me interesa señalar, respecto de la relación con modelos o tradiciones anteriores, que probablemente la mayor originalidad de Echeverría (la construc-

\footnotetext{
37 Esteban Echeverría, La cautiva [1837], en El matadero/La cautiva, ed. cit. de L. Fleming, pp. 117-222.

38 Sólo podría apuntarse la posible "latencia" del género silva-soledad (por ser las Soledades de Góngora el modelo) en algunos lugares del poema donde se habla de las "soledades" del desierto: “...en tus soledades deja / toda su alma..." (IX, vv. 127-128); "Se abisma en el fondo oscuro / de su propia soledad" (IX, vv. 165-166).
} 
ción de un personaje femenino "fuerte", enfrentado a la naturaleza y -hasta cierto punto- a la convención literaria) no llega a culminar. Como señala Operé, María es una "doble cautiva": en el nivel intradiegético, cautiva de los indios (y, simbólicamente, del desierto); en el nivel metadiegético, "está cautiva del texto romántico, que a pesar de las transgresiones narradas en los actos mencionados, acabará sometiéndola"39. Para 1837, la variante sentimental del romanticismo se había convertido ya en una convención de la que Echeverría tampoco puede escapar.

3. En relación con el peso de las formas-modelos metropolitanos, surge la cuestión de la ideología anclada en los contenidos culturales recibidos de la tradición colonial. A tal respecto, ¿es consciente el poema largo hispanoamericano de sus carencias y de sus diferencias? ¿Puede el poema largo hispanoamericano del XIX permitirse ser subversivo? 40 .

En los poemas de Heredia y Bello la representación de las guerras de independencia no logra ocultar un fondo de reconocimiento a la insoslayable presencia española y el género no parece mostrarse consciente de su diferencia respecto de la conciencia colonial, ni parece evidente la decisión de abrirse a posturas radicalmente subversivas. En Al Popocatepetl ${ }^{41}$ se sugiere un mensaje inequívocamente conservador que considera a la naturaleza como una continuidad superpuesta a la historia (en la medida, por ejemplo, en que el volcán generaba el mismo terror y la misma sumisión a los tlaxcaltecas que a los mexicanos contemporáneos: "Y el fiero tlascalteca / el ímpetu temiendo de tus lavas, / ante tu faz postrado / imploraba llorando tu clemencia”, vv. 23-26). De hecho, el fuego del volcán es interpretado alegóricamente (por los tlaxcaltecas, según el poeta) como "almas de tiranos" enviados a la tierra por el volcán. La naturaleza, así, sustenta un discurso moral-político, apoyado en una "falacia interpretativa": el poeta atribuye a los tlaxcaltecas su propia visión

39 Fernando Operé, “La cautiva de Echeverría: el trágico señuelo de la frontera”, $B H S, 80$ (2003), p. 551.

40 "... a prosperous life in the New World is unimaginable and inoperative if envisioned outside the authority of the immigrant's past. The nineteenth-century Canadian long poem, more conscious of what its subject matter lacks than of what establishes its difference, cannot afford to be subversive" (S. Kamboureli, op. cit., p. 12).

41 J. M. Heredia, Al Popocatepetl [1820], en Niágara y otros textos..., ed. cit., pp. 101-106 
del volcán y prepara una eventual aplicación contemporánea. Imagina, entonces, la posible destrucción total generada por el volcán (vv. 33-53), comparada, por otro lado, con un modelo europeo (el Etna), pero le parece una "espantosa idea" que quiere alejar de sí. Conforme se avanza en la lectura, se hace más evidente que el poema no es mera descripción, sino intuición de un posible destino histórico, que es preferible evitar. La analogía de esa destrucción volcánica con la destrucción generada por el diluvio permite además introducir una reflexión sobre la subordinación de la historia a la naturaleza, en el caso de dos monarcas que cesan en sus querellas al enfrentarse al rigor de la naturaleza, algo que, sin embargo, de nada les sirve: “...los furores del mar les alcanzaban, / que con ellos y su odio sepultaban / su reconciliación y su memoria" (vv. 89-91). Las guerras humanas son vanidad, parece sugerirse, frente a la incontrastable y eterna fuerza de la naturaleza.

Ese hipotético mensaje conservador (no subversivo) es detectable todavía con más claridad en el Niágara. En este poema, la reflexión política deja su lugar al lamento por el destierro individual. En esas circunstancias, el yo sólo pone su confianza en Dios y en la fama. Ese salto hacia lo íntimo se ratifica en Placeres de la melancolía ${ }^{42}$. En este poema, la referencia al pasado cultural se cifra en la posibilidad de entregarse al estudio de civilizaciones pasadas, pero ya la lección que se extrae de ellas es de carácter estoico: esas civilizaciones sólo enseñan la pervivencia del sepulcro y la ruina. Para Heredia, la vida se ha convertido en "delirio" marcado por el sentimiento de exilio y su conclusión es el desengaño, al punto de que frente a la tumba del padre ni siquiera se atreve a pronunciar una palabra "funesta”: “...junto / a tu polvo sagrado / reclinaré mi polvo atormentado, / que al eco de tres sílabas funestas / aun allí temblará..." (vv. 232-236). Acaso esas tres sílabas sean las de la palabra "libertad", que hacen temblar todavía al sujeto del poema, pero que el enunciador del mismo no es capaz de volver a escribir ${ }^{43}$.

42 J. M. Heredia, Placeres de la melancolía. Fragmentos [1825], en Niágara y otros textos..., ed. cit., pp. 115-122.

${ }^{43}$ Conviene, no obstante, mencionar que una nota al pie en la edición de las poesías de Heredia hecha en Barcelona en 1840, según AltenberG, reza: "Son estas [sílabas]: "Heredia» y era el apellido de su padre" (op. cit., p. 44). Altenberg prefiere dejar de lado toda consideración sobre la "plausibilidad" de esa nota. 
El caso de Bello es, en este aspecto, menos controvertido: en ningún momento renuncia a la "españolidad" de América. El Nuevo Mundo que propugna en sus silvas está ya modificado por la presencia española, cuya acción defiende ${ }^{44}$. Más que la definición de una identidad completamente nueva, lo que en sus poemas propone es, definitivamente, un regreso a los orígenes perdidos en Europa.

Para la interpretación de La cautiva desde este punto de vista hay que recordar lo dicho antes respecto de la inconcreción final del rasgo más subversivo del poema: la elevación de la mujer como el sujeto "fuerte" y su sometimiento final tanto a los escrúpulos de su marido Brian como a las convenciones del poema y de la pasión románticas. Operé sugiere que la eventual "feminización del discurso" en el poema funge como estrategia de oposición a la tiranía (masculina) de Rosas. Pero en realidad la feminización afecta a Brian (ese ser "inmoble"), más que al discurso: de hecho, se podría sostener que María se masculiniza en contacto con la barbarie y vuelve a su papel tradicional en cuanto recupera el contacto con la civilización. Además, para limitar el alcance subversivo de $L a$ cautiva no hay que olvidar que incluso el arquetipo de la mujer fuerte tenía importantes modelos (las viragos y otras mujeres "decididas" y discretas de la tradición clásica). De hecho, siempre se sostendrá que la energía que provee a sus denuedos es el "amor" y que su fuerza está relacionada con su condición de "ente divino" (VI, v. 46), algo, a fin de cuentas, también tradicional.

4. Se podría, entonces, sostener que el "poema extenso romántico hispanoamericano" se ve también afectado por lo que Kamboureli llama la "doble mirada" colonial: no se despega absolutamente del pasado y pondrá en marcha estrategias más o menos explícitas que mantienen los lazos simbólicos con la metrópoli, al tiempo que procura proyectarse hacia el futuro, inyectando sentido en los huecos detectados en ese discurso ${ }^{45}$.

44 Como indica F. Lauterbach, art. cit., p. 185.

45 “...the doubleness of the colonial gaze. The gaze backwards is one that fosters the emulation of generic conventions, one that perpetuates the symbolic ties with the mother country by subordinating the present to the past. The second direction of the gaze of recollection will come gradually to articulate the difference between the symbolism (the signified) of the mother country and the semiosis (the signifier, the inscribed) of the new country. It is engendered by looking forward, by gazing at the gaps in inherited patterns of meaning" (S. KAMBOURELI, op. cit., p. 25). 
La presencia del discurso colonial se detecta ya en Heredia, a través de la más que posible inspiración en pasajes de algunas crónicas de Indias para describir el Popocatepetl y para recordar algunas hazañas españolas en relación con el volcán. Por otro lado, en el mismo poema, la presencia ya aludida del sueño como estructura imaginaria, inspirada de modo más o menos directo en sor Juana, consigue instalar en el discurso la escisión entre mirada retrospectiva y mirada prospectiva: "A tu vista mi ardiente fantasía / por edades y tiempos va volando" (vv. 54-55). Como señala Albin en este caso, tanto para Al Popocatepetl como para En el teocalli..., "la mirada del sueño es más profunda que la vigilia porque se remonta al pasado y predice el futuro, es la mirada del visionario y del profeta" y "el sueño profético genera una poética de denuncia basada en el testimonio onírico" 46 . Es ésta, en esencia, la dualidad entre historia y mito, que denuncia los actos de violencia pasados y confía en el restablecimiento de un espacio utópico en América ${ }^{47}$. Es preciso, no obstante, señalar que la denuncia no incumbe tan sólo al período colonial, sino que se extiende hasta la censura del pasado azteca, por su carácter despótico y pagano, que motivó su desaparición (como dice en En el teocalli...: "su vil superstición y tiranía / en el abismo del no ser se hundieron”, w. 122-123). Justamente, la pirámide o "teocalli" desde la que el sujeto emite su discurso es el símbolo de esa superstición y tiranía.

En el Niágara, la doble mirada aparece también cancelada. El desengaño respecto del alcance de la acción revolucionaria y de las posibilidades de realización del proyecto político personal, llevan al poeta a fijarse en una "maravilla" natural admirable. Este rasgo tiene parangón con la única proyección hacia el futuro que el poeta contempla: la de la fama que le pueda reportar su poema, al margen de cualquier proyecto revolucionario.

En Bello, de nuevo, el problema parece más complejo: en su propósito está cantar una posible independencia cultural hispanoamericana combinada, sin embargo, con modelos antiguos neoclásicos ${ }^{48}$. El alcance de ese proyecto de independencia lite-

46 María C. Albin, "Mito e historia en la poesía de José María Heredia”, Hf, 2002, núm. 135, pp. 99-100.

47 M. C. Albin, art. cit., p. 102.

48 Alan S. Trueblood, "Las Silvas Americanas de Andrés Bello", Cultura Universitaria, 1947, núm. 4, 46-74, recogido en Historia y crítica de la literatura hispanoamericana, ed. C. Goic, Crítica, Barcelona, 1991, t. 2, pp. 121-129. 
raria, como ya se vio, es limitado ${ }^{49}$. Bello en ningún momento se propuso cancelar la referencia al pasado hispánico, sino más bien poner a disposición de los lectores de las nuevas repúblicas un caudal de conocimientos que asentaran una nueva civilización ${ }^{50}$. Si la Poesía debe instalarse en América no es porque exista entre ambas una consustancialidad ajena a la historia, sino porque en Europa se han corrompido las circunstancias que la albergaban adecuadamente. Es una corrupción lingüística e ideológica, como dice la Alocución: "donde la libertad vano delirio, / fe la servilidad, grandeza el fasto, / la corrupción cultura se apellida" (vv. 42-44). La "otra mirada", expresada en A la agricultura..., por el contrario, permite descubrir que en el campo se puede recuperar la pureza del idioma, del "lenguaje inocente / que los afectos sin disfraz expresa” (vv. 186-187).

A pesar de todo, no parece que el "poema extenso" fuera el género más adecuado para integrar esa "doble mirada" en ninguno de los tres autores que estamos considerando. El fragmentarismo que caracteriza a una posible interpretación de los poemas de Bello ${ }^{51}$ y también a alguno de Heredia (Placeres de la melancolía $)^{52}$, así como las incoherencias y debilidades formales en La cautiva de Echeverría, son índice de esta posible crisis del género. El caso de Bello ha sido bastante bien estudiado. Tanto si se interpreta que la Alocución y A la agricultura... son textos independientes que, a posteriori, podrían haberse integrado en un poema unitario titulado América, como si se considera que son "fragmentos" desprendidos de un proyecto general de ese título ${ }^{53}$, la cuestión del fragmentarismo afecta a ambos textos: la Alocución lo explicita en su subtítulo ("Fragmento de un poema titulado América"). A la agricultura ... va precedida de un título general ("Silvas americanas") y se acompaña de la siguiente nota en su publicación en el Repertorio Americano:

49 “...cantar las guerras de la independencia no supuso una ruptura con la formación adquirida, sino el desarrollo lógico de sus posibilidades de acuerdo con las circunstancias políticas" (TEODOSIo FERNÁndEZ, La poesía hispanoamericana [hasta final del modernismo], Taurus, Madrid, 1989, p. 107).

50 Tal era el sentido didáctico del prospecto en que Bello anunciaba la publicación del Repertorio Americano (revista donde se publicó A la agricultura... en 1826) según Trueblood (art. cit.).

${ }^{51}$ G. Araya, art. cit., p. 60.

52 Cf. T. Altenberg (op. cit., pp. 45-46). También la cuestión afecta a En el teocalli..., que en la edición de 1825 llevaba el título "Fragmentos descriptivos de un poema mexicano" (p. 154).

53 G. Araya, art. cit., p. 62. 
A esta silva pertenecen los fragmentos impresos en la Biblioteca Americana bajo el título América. El autor pensó refundirlas todas en un solo poema: convencido de la imposibilidad, las publicará bajo su forma primitiva, con algunas correcciones y adiciones. En esta primera apenas se hallarán dos o tres versos de aquellos fragmentos $^{54}$.

Como señala Gomes, Bello nunca explicó por qué canceló el proyecto. Esa decisión pudo tener que ver con la sospecha de que ese proyecto superaba las posibilidades de su "débil voz" (como dice al final de la Alocución) o con la conciencia de que ese poema América estaba escribiéndose casi de modo colectivo ${ }^{55}$. Pero también, como señala Gomes, la condición inconclusa y fragmentaria del proyecto literario estaría relacionada con la disipación del proyecto político unificador del pasado español y del espíritu independiente, es decir, con la imposibilidad de sostener una "doble mirada", en un contexto en el que las nacionalidades independientes propendían a la disgregación y a la fragmentación de América ${ }^{56}$. A partir del momento en que alcanza esa convicción, Bello abandona los géneros "miméticos" y opta por los géneros que Gomes llama "transitivos" (esto es, que influyen en el mundo: ensayo, discursos, tratados, estudios) y por una postura más convencionalmente romántica.

En el caso de La cautiva es más compleja la detección de esa "doble mirada" sobre la tradición colonial y sobre el proyecto ideológico independiente. Según Sosnowski, en el poema de Echeverría podría intuirse el deseo de construir una nueva tradición, por medio de la variedad de autores mencionados en los epígrafes de cada una de las partes del poema ${ }^{57}$. No es ésa, con todo, una tradición que excluya el modelo metropolitano

${ }^{54}$ Apud M. GoMEs, art. cit., p. 123.

${ }^{55}$ En 1826 Bello publicó una nota sobre la Victoria de Junín. Canto a Bolívar de Olmedo, donde le reconocía "el primer lugar entre todas las obras poéticas inspiradas en la gloria del Libertador" (apud M. GoMes, art. cit., p. 123; cf. también G. Araya, art. cit., pp. 68 ss.).

56 "[América] desoía el entusiasmo agrícola de la segunda silva y hacía de América soledad mortuoria de campo de batalla y no fértil soledad rústica... Bello, consecuente con sus creencias miméticas, es decir, neoclásicas, debió dejarlo amargamente incompleto y en escombros, tal como la América postindependentista se le presentaba..." (M. GomEs, art. cit., p. 194).

${ }^{57}$ Saúl Sosnowski, "Echeverría", en Historia de la literatura hispanoamericana. Del neoclasicismo al modernismo, coord. L. I. Madrigal, Cátedra, Madrid, 1981, t. 2, pp. 315-322. 
(ahí aparecen Calderón y Moreto), sino que lo integra al lado de otras tradiciones europeas: es de hecho la misma "culta Europa" de Bello (Dante, Byron, Hugo, Lamartine, Manzoni) y aun el Oriente filtrado por ella (Antar, poeta árabe traducido por Lamartine) la que proporciona el armazón paratextual de este poema sobre el territorio "inculto" e independiente del Desierto. Por otro lado, ese Desierto es el espacio en el que se confronta la doble perspectiva sobre las posibilidades de construcción de la "nación argentina" independiente, en conflicto con la "cuestión del indio". El "hueco", que en la tradición colonial hubiera correspondido a esa cuestión, lo llena Echeverría pero en un sentido poco integrador: anatematizado casi constantemente como "chusma" brutal y salvaje, el indio termina cediendo su espacio en el poema a una imagen ideal de la heroína María, lo que quizá tiene algo que ver con el triunfo del ideal criollo por sobre la naturaleza hostil y las amenazas del mestizaje ${ }^{58}$.

5. En tal sentido, la integración en la materia de los poemas de contenidos directamente relacionados con el pasado colonial está probablemente ligada con el proceso de conversión del poema en "institución cultural". Ignorar ese pasado, no posicionarse con respecto a sus valores y hazañas hubiera supuesto una textualización deturpada de la cultura americana en su origen ${ }^{59}$.

La reflexión sobre algunas hazañas bélicas del período de la conquista es en Heredia un modo de dar lugar a ese pasado colonial, en el que se reconoce una fuerza de la que habían carecido las culturas prehispánicas. Así, se evoca con admiración la hazaña "prometeica" de Ordaz y Montaño, que fueron capaces de arrancar el fuego al volcán (Al Popocatepetl): “...Montaño valeroso, / la voz de honor oyendo que le anima, / baja a tu ardiente sima, / y tus frutos te arranca victorioso" (vv. 193-196). Pero igualmente importante es que esa hazaña de raigambre mítica tuvo unas consecuencias histórico-políticas: las fuerzas de la naturaleza (el azufre arrancado al volcán) fueron utilizadas para someter a los

\footnotetext{
58 Tal es la conclusión (expresada de modo quizá demasiado tajante) del estudio de F. Operé: "La María de La cautiva simboliza la Argentina criolla, la nueva y soberbia nación a la que Echeverría aspira en puja por resurgir liberada de las amenazas del mestizaje y la hibridez cultural" (art. cit., p. 548).

59 "From being a cultural non-text, the colony gradually becomes a museum preserving the feats and values of Britain. As a repository of monuments, the nineteenth-century long poem posits itself as a literary institution..." (S. Kamboureli, op. cit., p. 17).
} 
indígenas (fabricando pólvora). Parece sugerirse que el dominio de la naturaleza otorga el dominio de la historia. Por otro lado, teniendo en cuenta la deriva "conservadora", desengañada, de Heredia en otros dos poemas que estamos considerando, no extrañará la adscripción en ellos a valores propiamente coloniales: el giro religioso de Niágara o la comprensión pesimista de la historia (colonial e independiente) como lección de atrocidad que se expone en la sección IV de Placeres de la melancolía.

De nuevo, Bello presenta, a este respecto, una elaboración más compleja. En sus poemas, la cultura americana se va configurando como una "expansión" de la europea, y, en ese sentido, como una "cultura colonizada" o "heredera", más que como una cultura original innovadora. En la Alocución, el sintagma "también allí", referido a América y repetido, implica una comunidad de capacidades y valores entre los dos mundos: perdidos circunstancialmente en el Viejo y aún presentes en el Nuevo, pero sin ninguna diferencia esencial. En América se re-producen las condiciones para la poesía que una vez estuvieron y ya no están en Europa (el valor heroico o el espacio amoenus). Prácticamente todo lo que se traiga del Viejo Mundo puede aclimatarse en el Nuevo (en A la agricultura... se lee: "la manzana y la pera / en la fresca montaña / el cielo olviden de su madre España", vv. 215-217). En el "Allî"-América de la Alocución (v. 11), de modo poco realista, soplan los mismos vientos y cantan casi las mismas "avecillas". América es el lugar desde donde se debe regenerar el canto, pero desde donde todavía no habla el poeta, que está ubicado aún en "esta región de luz y de miseria" (v. 34) que es Europa. El yo se siente constreñido en ese espacio y al reclamar la translatio de la poesía, está procurando también ser transportado "allî" por su propio discurso. La textualización de la cultura americana, en Bello, comienza a realizarse en Europa, como movimiento intencional de reubicación en el espacio del cual el poeta ha salido y al cual puede llegar llevando (o siendo llevado por) la poesía. La escritura de la Alocución es, en tal sentido, también una restitución.

Sin embargo, ese proyecto, latente en los dos poemas de Bello, adopta de nuevo valores tópicos de la cultura metropolitana en su período colonial: las razones para la translatio de la poesía se equiparan con el tradicional menosprecio de corte (Europa) y alabanza de aldea (América), traducido a veces de modo directo: se menosprecian los "dorados alcázares reales", la "turba cortesana" y la "servil lisonja" (Alocución, vv. 25-28); o bien “...del 
necio y vano / fasto, el mentido brillo, / el ocio pestilente ciudadano!" (A la agricultura..., vv. 72-74). En el segundo poema, no obstante, la oposición corte/aldea ha verificado ya, de hecho, el movimiento de traslación y se emite como reproche a los terratenientes criollos, que "en el ciego tumulto se aprisionan / de míseras ciudades" (v. 81-82). La ciudad americana es tristemente idéntica a la europea como ámbito de vicios ("ilícitos amores", v. 96; "ruinoso juego", v. 98) y el discurso de Bello adopta también un tono satírico-didáctico tradicional. El proceso de restitución, definitivamente, debe elevarse a las fuentes de la cultura: Roma ("No así trató la triunfadora Roma / las artes de la paz y de la guerra; / antes fió las riendas del estado / a la mano robusta / que tostó el sol y encalleció el arado", vv. 125-129). De ese modo, queda establecido el origen de la institucionalización cultural-literaria de América en una fuente idéntica a la europea.

Por esa razón, la posible inspiración de la Poesía americana en leyendas o en los climas autóctonos queda en los poemas de Bello como una mera alusión al pasar (Alocución, v. 123). Lo verdaderamente importante consiste en trasladar el modelo cultural clásico. En ese sentido, la Alocución podría entenderse como una suerte de "poema virtual". Su composición se ve afectada por un problema no resuelto: el de quién pondrá los medios para que la "Divina Poesía" (v. 1) "deje ya la culta Europa" (v. 7). El poema no dice exactamente dónde se instalará la poesía ("la grande escena" abierta por el mundo de Colón, v. 10, parece demasiado inconcreta), ni tampoco dice quién podrá llevarla a América, ni cuáles habrán de ser sus temas concretos. En la medida en que el poema sólo augura que ello suceda en un futuro (no menos impreciso), la Alocución es un poema utópico que refleja otro poema "virtual", aún por escribir. En la medida, también, en que el sujeto que habrá de realizar ese poema está modelado sobre el patrón virgiliano, es un poema neoclásico que sólo considera posible el surgimiento de una poesía americana si son asimilados los modelos de la cultura occidental: "Tiempo vendrá cuando de ti inspirado / algún Marón americano, joh, diosa! / también las mieses, los rebaños cante" (vv. 189-191). No obstante, el logro de mayor modernidad de la Alocución viene dado por su carácter performativo: al anticipar que el tema para ese poeta habrá de ser las "dádivas mil" que el propio poema describe, el "yo" que habla en este poema se convierte en ese "Marón americano", y la mera existencia del poema Alocución realiza la traslación de la poesía a América. Por ese valor performativo (que consiste en 
realizar aquello que se dice), la Alocución se convierte, entonces, en el primer monumento poético americano (aun cuando, significativamente, sea un monumento fragmentario o inconcluso).

Por ese motivo también, la imagen del período colonial que allí se fragua adquiere un matiz paradigmático, al margen de que correspondiera o no con la interpretación real del propio Bello. La Alocución refleja un período de "usurpación" ("No largo tiempo usurpará el imperio / del sol la hispana gente advenediza", vv. 274-275); la presencia española es vista con rasgos monstruosos (como un "coloso de bronce / a que tres siglos daban firme basa", vv. 300-301), sin embargo, por contraste con la dominación colonial contemporánea, se "dulcifica" el período de conquista: "Pudo a un Cortés, pudo a un Pizarro el mundo / la sangre perdonar que derramaron; / imperios con la espada conquistaron" (vv. 555-557); o bien el duque de Alba "...si fue crüel y sanguinario, / bajo no fue; no acomodado al vario / semblante de los tiempos su semblante" (vv. 570-572). Por eso este monumento que es la Alocución es consciente de los riesgos que se corren al fundar un género nuevo (la silva independentista, si seguimos a Gomes) o una tradición poética: la poesía de la edad presente sólo puede ser poesía de la guerra actual y, dadas las circunstancias en que ésta se ha desarrollado, su textualización puede resultar inverosímil: "puede ser que parezcan tus verdades / delirios de estragada fantasía / que se deleita en figurar horrores" (vv. 598-600). Por eso, A la agricultura... reclama otros temas para la poesía americana: "Asaz de nuestros padres malhadados / expïamos la bárbara conquista" (vv. 302-303). El trabajo que espera al hombre y al poeta americano es una tarea de restauración, que impone un cambio de época y el olvido de la rivalidad entre la ideología hispánica y la prehispánica: “¿Cuántas doquier la vista / no asombran erizadas soledades, / do cultos campos fueron, do ciudades? / De muertes, proscripciones, / suplicios, orfandades, / ¿quién contará la pavorosa suma? / Saciadas duermen ya de sangre ibera / las sombras de Atahualpa y Motezuma” (vv. 304-311). Sólo la dedicación al campo, la construcción de una "utopía agraria", que sintetice y haga fructificar la doble herencia, dará más fama todavía a las hazañas bélicas y heroicas.

Echeverría, no obstante, ignora una vez más el programa de Bello: las sombras indígenas y la sangre criolla (y en el fondo ibera) vuelven a teñir La cautiva. Contra la propuesta de Bello, el programa nacional de Echeverría parece anticipar el reclamo 
sarmientino de "no economizar sangre" 60 : los indígenas aparecen como "sedientos vampiros" (II, v. 73) que beben la sangre de los caballos; la primera aparición de María la muestra con un "puñal sangriento" que será clave en el desarrollo del poema (III, v. 37). El inicio del poema de Echeverría, entonces, retoma el tema del conflicto, como origen de la identidad independiente. Y en ese conflicto habrá de ser la identidad criolla-blanca, inspirada por los valores occidentales, la que se imponga. La demonización del indígena es constante a lo largo de todo el poema ${ }^{61}$ y paralela a la idealización de la figura de María ${ }^{62}$. De hecho, el indígena casi desaparece del poema a partir del canto III, desde el momento en que Brian y María huyen. El borrado de su presencia en el poema puede ser paralelo a la instauración de un principio ideológico de carácter conservador: la asunción de los valores paternalistas y patrióticos, siempre focalizados en la figura de Brian, cuya "inmovilidad" física (reiterada a lo largo de todo el poema) hace eco a un inmovilismo moral de carácter "ultramontano" ("Del salvaje la torpeza / habrá ajado la pureza / de tu honor..."; III, vv. 191-193) y a una concepción del patriotismo que, según el mismo Brian, dignifica su propia muerte (VIII, vv. 234-237, 242), hasta concluir con un reclamo patético:

60 Sarmiento se refiere, como es sabido, a la de los gauchos en la famosa carta a Mitre de 20 de septiembre de 1861. F. Operé señala: "Muchos de los contenidos teóricos de Sarmiento están sugeridos en La cautiva, especialmente la perniciosa evaluación de la frontera" (art. cit., p. 548).

${ }^{61}$ No hay una sola referencia positiva: tribu errante (I, v. 21), turba inmensa (v. 108), insensata turba (v. 121), bando de salvajes (vv. 131-132), el bárbaro (v. 141); II: tribu aleve (v. 19), turba (v. 43), chusma (vv. 58, 115), sedientos vampiros (v. 73), abominables fieras (v. 98), tribu (v. 109), inmunda ralea (v. 136), la indiada (v. 155), indio guapo (v. 175); III: salvaje turba (v. 3), salvajes (vv.42, 191, 206), gente fiera (v. 84), tribu impía (v. 131), bárbaro traidor (v. 135), turba inhumana y fatal (vv. 229-230), indios inhumanos (v. 329); IV: tribu infiel (v. 20), chusma (v. 30), salvaje (v. 69); V: salvaje (v. 23); VIII: salvajes (v. 139), bárbaro (v. 149); epílogo: tribu errante (v. 73), el indio exorcista (v. 85). Sólo las mujeres indias reciben un tratamiento algo más positivo (II): se interponen en las matanzas del festín.

${ }^{62} \mathrm{~F}$. Operé ha señalado que la opción de María (fugarse) no fue la única: muchas cautivas hubo que realizaron labor de mediadoras entre la población indígena y la blanca y algunas no quisieron volver a territorio "cristiano" (art. cit., p. 548). "Sin embargo, la carga ideológica del poema caracteriza a María como un ser sublime en una gesta de tonos epopéyicos cuyo fin mediato es salvar al amante y salvarse a sí misma de los horrores de una posible mutación o mestizaje, que en la perspectiva romántica podría interpretarse como pérdida de la pureza racial y cultural" (p. 549). 
“ ¡Si al menos la azul bandera / sombra a mi cabeza diese!” (VIII, vv. 258-259).

Pero, más allá de la presencia de principios ideológicos de carácter conservador en el momento de la construcción de una tradición poética nacional, La cautiva ofrece aún otro interés para el aspecto que ahora estoy considerando: se trata de la conciencia metapoética que eleva al texto como "institución" cultural, en un gesto pragmático análogo al valor performativo de la Alocución de Bello. La historia de María y Brian está destinada a convertirse en leyenda fundacional, como revela el epílogo, y en ese proceso el poema La cautiva es la primera muestra de que “...la viva palabra / un monumento le labra / que el tiempo respetará” (IX, vv. 134-136). El poema es, entonces, el ejemplo primero de esa "virgen poesía" que en el epílogo conservará los nombres de María y Brian. En ese movimiento final el poema extenso -como ocurría en el caso de Bello- se presenta como textualización consciente del origen de una cultura.

6. En este punto es en el que empieza a establecerse la correlación más estrecha entre la forma-género del poema extenso y la materia de dichos poemas. Se trata ahora de indagar en la posibilidad de conservar un eventual ethos épico-distinto pero mantenido más allá de la cancelación de los rasgos formales del género-, a través de la atención concedida al medio ecológico y cultural, una vez superado el contexto conflictivo de configuración de la identidad colectiva ${ }^{63}$.

$\mathrm{Al}$ hablar de la importancia de la forma-género de la "silva" ya se insinuó (con Gomes) la correspondencia metafórica entre texto y espacio. El reclamo de cambio de época, de considerar suficiente la "sangre ibera" derramada, que aparecía en Bello, apunta que un ethos épico-bélico ya no puede ser el tono dominante de la gran poesía americana. Por el contrario, ésta debe volverse hacia la conjunción de naturaleza y cultura, y los residuos épicos, si acaso, habrán de reaparecer en el conflicto entre

63 "The colonial poet's nostalgia accounts in part for the frequent preference for the epic form... although there are many long poems in the nineteenth century that, strictly speaking, are not epic. Their intent, however, evokes it. Their emphasis lies not so much in imitating the features of the classical, medieval, Renaissance, and later forms of epic as in attempting to emulate epic ethos... The epic ethos manifests itself in accordance with the ecological and cultural milieu..." (S. Kamboureli, op. cit., p. 22). 
una y otra, esto es en la transformación de selva en campo, o, como se ha dicho, a la representación de una utopía agraria.

Ya Heredia reclamaba al final de $A l$ Popocatepetl la necesidad de prosperar en la "fértil hacienda", si la naturaleza violenta permite el sosiego. El mensaje, no obstante, es -de nuevo- conservador, pues con el alcance alegórico que se señaló antes para este poema, se está postulando un "olvido" de los agravios legendarios e históricos (proyectados imaginariamente sobre el volcánvíctima). También En el teocalli... comienza con la descripción de una "utopía agraria": Anáhuac -el territorio azteca- se muestra como una especie de edén, que, sin embargo, puede desaparecer por las guerras endémicas (esto es, por la imposición de los condicionantes históricos sobre la naturaleza). La estabilidad sobre la que ha de construirse esa "fértil hacienda" es, entonces, precaria y el lamento que aparece en Placeres de la melancolía por una historia que ha sido siempre en América lección de atrocidades deja testimonio de esa precariedad. Parece afirmarse en la poesía de Heredia que el ethos épico es insuperable en la realidad americana y que, en el nivel poético, sólo es sustituible por el desengaño y la queja elegíaca.

La "utopía agraria” encuentra en Bello, desde luego, la más acabada representación, especialmente en A la agricultura... como ya ha habido ocasión de señalar. En este punto, apenas conviene recordar que el reclamo de superación del ethos épico (de una edad heroico-bélica) pasa por ocuparse de la naturaleza cultivada: el campo se ofrece de modo decidido como el espacio para la acción propiamente americana: "el campo es vuestra herencia; en él gozaos" (v. 147). La energía heroica debe proyectarse hacia el dominio de la naturaleza, que dará aun mayor grandeza que la acción bélica: "Las gentes a la senda / de la inmortalidad, ardua y fragosa, / se animarán, citando vuestro ejemplo. / Lo emulará celosa / vuestra posteridad; y nuevos nombres / añadiendo la fama / a los que ahora aclama" (vv. 359-365).

La respuesta de Echeverría parece ligeramente distinta en la década siguiente. En La cautiva, el ethos épico, la confrontación bélica directa apenas aparece aludida (y sólo de modo elíptico) en la primera parte -en las referencias a la "maloca"- y en la cuarta, donde se presenta la venganza "cristiana". A Echeverría le interesa más la confrontación de los personajes con un espacio autónomo y autóctono, hasta cierto punto hostil. El poema extenso confiere a esa confrontación la amplitud adecuada. En la "Advertencia" inicial subraya la importancia de un trabajo de 
selección para destacar los "colores locales" y los "peculiares ornatos de la naturaleza” (p. 117). El espacio del Desierto (con mayúscula) se convierte en el origen de la riqueza natural y cultural en el momento de construcción de la identidad nacional, según Echeverría:

El Desierto es nuestro, es nuestro más pingüe patrimonio, y debemos poner nuestro conato en sacar de su seno, no sólo riqueza para nuestro engrandecimiento y bienestar, sino también poesía para nuestro deleite moral y fomento de nuestra literatura nacional (v. 117).

La lucha será entonces contra el Desierto. Por eso, a lo largo del poema la presentación realista de ese espacio será quizá menos importante que la presentación moral-alegórica como espacio de cautiverio para la heroína. Hay, no obstante, algún pasaje en el que se alude a la "devorante sequía” (VII, v. 50) que propicia el incendio causado por la "chispa de una hoguera" (v. 52), mínimo apunte ecológico que, sin embargo, se eleva a valor simbólico como un nuevo elemento que endurece el cautiverio y la lucha por la vida de los protagonistas.

7. Por fin, hay que señalar que, en semejante proceso de construcción de un espacio textual-cultural de carácter nacional no épico, las dimensiones del poema serán esenciales por lo que tienen de mecanismo de afianzamiento de la visibilidad del mensaje. Pero también porque explícitamente presentan una correlación con las dimensiones del espacio real en el que pretenden fundamentar las bases de la identidad cultural americana ${ }^{64}$.

En Heredia, las dimensiones del objeto representado en sus poemas descriptivos (el volcán, la pirámide, las cataratas) son fuentes de sublimidad típicamente romántica (especialmente en el Niágara), pero que se atribuye también a otras épocas (el terror es la respuesta tanto de los tlaxcaltecas como de los mexicanos contemporáneos ante el Popocatepetl, como ya dije). En el teocalli... es justamente el espacio inmenso ante el que se encuentra el poeta lo que pone en marcha la fantasía que redundará en el poema: "El llano inmenso que ante mí yacía, / los ojos a espaciarse convidaba" (vv. 44-45) y cuando más adelante se refiera a

${ }^{64}$ Como muchos críticos del long poem canadiense sugieren, según $\mathrm{S}$. KAMBOURELI (p. 23). 
"Esta inmensa estructura" (v. 130), evidentemente alude a la propia pirámide desde la que se produce la enunciación, pero ya no podremos dejar de pensar en que, indirectamente, apunta al poema que de ella habla ${ }^{65}$.

La ya aludida homología entre "silva" y "selva" es la más evidente correlación entre las dimensiones de los poemas de Bello y su materia. Pero también existen otros índices más explícitos. Al final de la Alocución aparece la metáfora de un árbol gigante para representar la vasta materia: “... aquel samán que siglos cuenta” que “...vasto espacio cubre con la hojosa / copa..." (vv. 825, 829) y sus dimensiones se comparan con la magnitud de la hazaña del "Libertador del pueblo colombiano", que Bello se considera incapaz de cantar.

En el caso de La cautiva la correlación entre las dimensiones del poema y las de la materia cantada son explícitas desde el epígrafe de Hugo que abre la primera parte: Ils vont. L'espace est grand ${ }^{66}$. Estas palabras resumen cabalmente la acción y las dimensiones del poema: éste va a cantar básicamente una larga peregrinatio funesta ${ }^{67}$ a través de un Desierto "inconmensurable, abierto" (I, v. 4) o un "ilimitado horizonte" (IX, v. 74) y se ha de servir para ello de un texto de dimensiones amplias. En cierto sentido, el texto (como el crepúsculo al principio del poema) "reconcentra / [la] inmensidad" del Desierto (I, vv. 11-12) y sólo un poeta inspirado podrá construirlo cabalmente: "Sólo el genio su grandeza / puede sentir y admirar" (I, vv. 49-50).

Las dimensiones del Desierto, por otro lado, sólo son comparables a la magnitud de las fuerzas de la protagonista, que apenas se agotan cuando traspasa la frontera, de regreso a la civilización ${ }^{68}$. Desierto, espíritu de la protagonista y texto com-

${ }^{65}$ El problema de lo sublime en Heredia, con particular atención a la función de la naturaleza en los poemas que me ocupan, pero sin referencia a la cuestión de la dimensión textual, ha sido detalladamente explicado por T. Altenberg (op. cit., pp. 232-249), quien también ha atendido a la cuestión de la filiación histórico-literaria del autor (véanse pp. 13-14, 197-232).

66 Algunos otros epígrafes también tienen referencias a las dimensiones: así la "vasta pianura" de Manzoni (IV: "La alborada", p. 161); que resuena en el Epílogo en la "vasta llanura" -v. 49- donde destaca la cruz que recuerda la muerte de los protagonistas; o la referencia a la duración de la acción en el epígrafe de Moreto: “Qué largas son las horas del deseo!” (VI: “La espera”, p. 175).

${ }^{67}$ Ya cerca del fin del poema se dice: "cuán largo, incierto camino / la desdicha le previno" (VIII, vv. 41-42).

68 Así lo ve F. Operé: "Por un proceso de simbiosis, la heroína del poema parece estar alimentándose de las fuerzas incontrolables de la naturaleza que 
parten así el rasgo de sublimidad derivado de la grandeza y en esa correlación se cifra el propósito declarado de Echeverría de "pintar algunos rasgos de la fisonomía poética del desierto"69. $\mathrm{Si}$, además, se percibe que, explícitamente, la inmensidad del desierto es análoga a la del mundo (“...Vasto, profundo / como el páramo del mundo / misterioso es el que pisan”, III, vv. 311313), la proyección metafísica del poema resulta ya inequívoca. Por eso, el Desierto es la única sepultura adecuada para un alma como la de María, al igual que el poema es continente adecuado de su leyenda: "El Desierto la sepulta, / tumba sublime y grandiosa" ("Epílogo", vv. 29-30) al tiempo que el poema (no menos sublime y grandioso) la ensalza.

8. Así, vamos llegando a la conclusión, y es posible intuir que en la serie de poemas que ejemplifican los casos aquí presentados se empieza a esbozar el "gran salmo de la república" que buscará Whitman (1855), en un proceso de búsqueda de formas "sólidas y hermosas"70. Sin duda, los logros pueden ser cuestionables desde un punto de vista ideológico independentista (hemos ido señalando algunos reparos al respecto). Pero no cabe duda de que en poemas como los de Heredia, Bello o Echeverría se empieza a producir la fusión yo-naturaleza (paisaje)-historia (colectividad) ${ }^{71}$ que propiciará el surgimiento de una tradición poética nacional.

Heredia, en Al Popocatepetl, recuerda los agravios (mitológicos o históricos) infligidos al volcán y reconoce que su propio poema puede constituir un nuevo agravio que mueva la cólera de esa

a su vez la amenazan... María sucumbe ante la noticia de la muerte de su hijo, con lo que reasume su papel tradicional como objeto cosificado, atrapado en su corsé literario. Esto ocurre en el epílogo y tras haber cruzado de regreso la línea fronteriza camino de la civilización. Es decir, la María emprendedora, decidida, fuerte y varonil, tiene expresión dentro del ambiente natural, en tierra adentro, en el medio salvaje" (art. cit., p. 550).

69 "Advertencia", v. 117; las cursivas son mías.

70 "...the expression of the American poet is to be transcedent and new. It is to be indirect and not direct or descriptive or epic. Its quality goes through these to much more. Let the age and wars of other nations be chanted and their eras and characters be illustrated and that finish the verse. Not so the great psalm of the republic. Here the theme is creative and has vista. Here comes one among the well beloved stonecutters and plans with decision and science and sees the solid and beautiful forms of the future where there are now no solid forms" (W. Whitman, Prefacio a Leaves of grass, 1855; cit. por S. Kamboureli, op. cit., p. 22).

71 M. C. Albin, art. cit., p. 101. 
fuerza natural: “¿Con fuerza te estremeces? ¡ah! yo creo / que a cólera mi labio te provoca” (vv. 197-198). Parece sugerirse que la naturaleza desatada es más importante (a efectos de construir una nación) que la historia. Mágicamente, Heredia insinúa que no se debe provocar a las fuerzas naturales; lo que una vez fue violentado para conseguir el sometimiento (los españoles que usaron el fuego volcánico para doblegar a los tlaxcaltecas) debe ahora permanecer sosegado para no estropear los resultados positivos de ese proceso de construcción de una cultura hispanoamericana. De nuevo, es un mensaje conservador que concluye con una petición: que el volcán no destruya la tierra cultivada que lo rodea. El himno de la república comienza así con el reclamo de una "utopía agrícola".

Poco después, En el teocalli... reitera el reclamo moral presente siempre en la contraposición entre naturaleza e historia en estos poemas: en este caso, el silencio de la pirámide que fue símbolo de orgullo y crueldad da testimonio de la vanidad de la historia, que deben aprender los contemporáneos: “...y hoy al hombre / que ciego en su saber fútil y vano / al cielo, cual Titán, truena orgulloso, / sé ejemplo ignominioso / de la demencia y del furor humano" (vv. 147-151). De modo inequívoco se postula la superación del ethos épico, antes aludida.

En Bello, esa superación adopta la fórmula retórica de la preterición: aunque dedica la mayor parte de la Alocución a lo que Menéndez Pelayo fulminó como "padrón de vecindad" de los héroes de la independencia, Bello finge que ése podría ser el tema del "nuevo Marón”, del poeta futuro, pero no del poema que él está escribiendo. En Bello, como ha señalado Trueblood, predomina el elogio a la paz. Durante su estancia en Europa (momento en que compone sus silvas) la aversión a la guerra no hace sino incrementarse al contacto con los conflictos napoleónicos. Ese "pacifismo" se libera de modo inequívoco en $A$ la agricultura..., pero ya en la Alocución expresa claramente su renuencia a tratar el tema, que sólo la historia justifica en un programa patriótico: "¡Oh si ofrecieses menos fértil tema / a bélicos cantares, patria mía!” (vv. 212-213). Podría decirse que la guerra ha corrompido el lenguaje (igual que ha sucedido en Europa) en la medida en que la misma "fertilidad" califica al tema bélico y al natural que él pretende proponer. Aunque al poeta no le guste, también la musa épica (como ocurre con otros temas) es más rica en América que en Roma, Esparta o Numancia. Por esa razón, la extensión del poema puede estar relacionada con la 
"extensa" historia (fértil materia) bélico-rebelde de América: "Pero ¿a dónde la vista se dirige / que monumentos no halle de heroísmo?" (vv. 751-752). Ese es el "rico asunto" (v. 793) del que el poeta sólo podrá dejar "alguna parte breve" (v. 798).

Como ya se ha venido diciendo, la vida bucólica puede ser el modo de salir de ese "mundo épico". El trabajo de la tierra es el único modo de olvidar la guerra. El campo es el lugar para encontrar la paz: "cerrad las hondas / heridas de la guerra" (A la agricultura ..., vv. 203-204), “...tras tanta zozobra, ansia, tumulto, / tantos años de fiera / devastación y militar insulto" (vv. 274276). La "utopía agraria" de nuevo es el tema del himno republicano. En ella se abre la posibilidad de una nueva vida y de una nueva poesía, de la que el poeta quiere eliminar toda sospecha de "ciego error de ilusa fantasía" ( A la agricultura .., v. 223). El poema mismo quiere realizarla: “...la caterva / servil armada va de corvas hoces" (vv. 225-226) debe obedecer a la voz de la agricultura (como la agricultura -y en el poema anterior la Poesía- han de responder a la voz del yo).

En Echeverría, desde luego, la posibilidad de escribir ese salmo republicano se insinúa en el epílogo, que representa, metapoéticamente, el origen de la leyenda fundacional de María. La cautiva, como dije, se ofrece como la primera plasmación textual de dicha leyenda y, así, como el primer "monumento" poético de la Nueva Argentina, que ha vencido al Desierto.

9. En conclusión, cabría proponer que el género del "poema largo" funciona como gramática que ayuda a entender la tradición poética hispanoamericana ${ }^{72}$. Las oscilaciones enunciativas de la Alocución de Bello, el primer intento de poema-monumento americano, entre el "allí" al que debe irse a cantar y el "aquí", la paradójica "región de luz y de miseria” desde donde el poeta canta realmente, mostraron cómo esa nueva poesía americana surge, como proyecto, fuera de lugary sólo en el mismo instante de su realización (en un poema extenso, fragmentario e inacabado) llega poética y efectivamente a América.

72 Siguiendo a Todorov en esa concepción del "género" como "gramática" que proporciona parámetros de lectura, S. KAMbOURELI señala: "In spite of the various manifestations of genre in Canadian poetry, the long poem has always been there as a specific field, whether «in the traditional narrative form» that Frye hoped would be maintained or in the form of epic and extended lyric sequences" (op. cit., p. 27). 
Desde este punto de vista ampliamente "gramatical", además, no puede olvidarse que, en el marco de esa nueva poesía que opta por el discurso extenso, habrá de producirse la regeneración del idioma, como se postulaba en A la agricultura... La restauración idiomático-ideológica no excluye, por otro lado, una doble contaminación, sino que se apoya en ella: desde el punto de vista del enunciado, en esta América poética (título de la gran antología que en 1846 publicara Juan María Gutiérrez, asimismo, editor de Bello) convivirán el ananás y la ambrosía ("el ananás sazona su ambrosía" es un verso que se repite idéntico en Alocución -v. 198-y en A la agricultura-v. 39) o el "carmín" del nopal superará al "múrice de Tiro" (A la agricultura..., v. 24-25). Desde el punto de vista de la enunciación, la mera escritura del poema efectúa un desplazamiento en el sujeto del canto: si al principio es, insistentemente, la Poesía misma ("tú cantarás", v. 123), luego se desliza a la primera persona ("diré", vv. 754, 763, 769; "Contaré", v. 757; “citaré”, v. 776), para, finalmente, concluir melancólicamente en una tercera, representativa del "poeta virtual" en el cual Bello ha creído encarnar por un instante: "así el que osare con tan rico asunto / medir las fuerzas, dudará qué nombre / cante primero, qué virtud, qué hazaña" (vv. 793-795). El yo, entonces, declara su debilidad: "Mas no a mi débil voz la larga suma / de sus victorias numerar compete" (vv. 821-822). El poema largo hispanoamericano es frágil instrumento -en este período- para la representación del verdadero himno de la república.

El otro ejemplo mayor de los aquí seleccionados es La cauti$v a$. También en el poema de Echeverría se produce un cuestionamiento de la gramática poética. En tal sentido, podrían destacarse las inconsecuencias gramaticales adyacentes a los primeros usos del voseo en la poesía argentina, que ya suponen un reto a la convención genérico formal ${ }^{73}$. Pero también podría integrarse en este proceso de cuestionamiento del género el problema de las incoherencias argumentales (por ejemplo, la incierta muerte del hijo de Brian y María ${ }^{74}$ o la desaparición de los indios), que

73 Me refiero al pasaje "y su luto fuiste vos /.../ pero hoy tumba de un soldado / eres...” (IX, vv. 101, 104-105; las cursivas son mías), comentado por Fleming (en su introd. a El matadero/La cautiva de E. Echeverría, ed. cit.).

74 Cf. III, v. 210; VIII, vv. 152-153, IX, v. 245. Luego, sin embargo, parece que está vivo (VIII, v. 291): "Vive, vive para tu hijo" (aunque es recomendación hecha por Brian en medio de su delirio). María más tarde pregunta por 
está, necesariamente, relacionado con la extensión del poema (factor que las propicia y las "justifica”), pero también con la vastedad del Desierto y de la conciencia (a veces enajenada) de los protagonistas. La polimetría (que Echeverría aducía como uno de los mayores rasgos de originalidad y, por tanto, de cuestionamiento de la gramática genérica previa) está igualmente anclada en la extensión y la variedad tonal del poema, mediante la que se pretende cautivaral lector.

10. En suma, pues, el poema largo hispanoamericano del XIX consigue cuestionar, siquiera sea moderada y precariamente, la "gramática genérica" heredada de la tradición europea. Ello puede deberse a que -como sugiere Kamboureli para el caso canadiense- también en Hispanoamérica se ha producido -para este género- una superposición, en un marco temporal limitado, de rasgos genéricos de larga gestación europea ${ }^{75}$. El "poema extenso romántico" es, entonces, un testimonio más del proceso de asincronía que, especialmente durante el siglo XIx, afectó a la constitución de las literaturas independientes en Hispanoamérica. Y si, para terminar, intentamos resumir cuáles han sido los factores determinantes de ese proceso, podría proponerse la siguiente enumeración:

1) La vinculación poema extenso-contexto literario independiente sólo puede ser analógica, a través de la duración de los procesos y mediante la eventual interrupción de los mismos.

2) La presencia de modelos metropolitanos en la constitución de esta forma-género resulta evidente y, aunque en todos los autores hay un propósito de renovación, no puede hablarse de liberación absoluta de los patrones manejados.

su hijo, acaso igualmente trastornada por la experiencia (IX, v. 240), y cuando le informan de que está muerto ella también muere.

75 "Generic features that characterize the classical epic, the medieval romance, the narrative poem, and the cycles of lyric poems -genres that developed through a great span of time- are in Canada collapsed within the literature of roughly one century. This simultaneity of diverse forms challenges the grammar of genre as it developed in Europe" (S. KAMBOURELI, op. cit., p. 28). 
3) El poema largo romántico hispanoamericano, entonces, asume de modo bastante claro el pasado cultural en el que surge. Se muestra poco consciente de sus diferencias específicas y, aun cuando pueda eventualmente sugerir su puesta en juego, termina en un discurso de desengaño de un alcance subversivo bastante limitado.

4) En todos los poemas mencionados, el rasgo de la extensión, no obstante, se proyecta de modo explícito sobre las dimensiones de la materia cantada y cumple así el requisito romántico de sublimidad.

5) El poema extenso es, también, un lugar de crisis de la mirada escindida del poeta que escribe en la frontera entre la colonia y la independencia. No encuentra el modo de deshacerse del pasado colonial (en el cual bebe), ni de integrarlo de modo absoluto con el pasado prehispánico (que tampoco le sirve de modelo) o con el presente indígena o criollo. En cierto modo, esa "mirada estrábica" condena el género a su fragmentarismo y a su disolución en otros géneros (didácticos o "transitivos" o incluso en poemas narrativos de carácter menos problemático).

๑) No obstante, cabe decir que el poema extenso hispanoamericano, en el primer tercio del siglo XIX, sí es consciente de su papel como "institución cultural" o monumento poético, que asume de modo más o menos crítico el pasado colonial-hispánico como fuente de su identidad y realiza -en la escritura- el gesto de fundación de esa misma cultura independiente.

Daniel Mesa Gancedo

Universidad de Zaragoza 